\title{
Analisis deformasi pada coupling element dari automatic mechanical coupler: studi kasus LRT Palembang
}

\author{
Achmad Syaifudin ${ }^{1}$, Betti Mawar Kalista ${ }^{1}$ dan Agus Windharto ${ }^{2}$
}

\author{
${ }^{1}$ Departemen Teknik Mesin, Fakultas Teknologi Industri, Institut Teknologi Sepuluh Nopember \\ ${ }^{2}$ Departemen Desain Produk, Fakultas Arsitektur, Desain dan Perencanaan, Institut Teknologi Sepuluh Nopember \\ Jl. Raya ITS, Keputih, Kecamatan Sukolilo, Surabaya, Jawa Timur 60111
} Email korespondensi: saifudin@me.its.ac.id

\begin{abstract}
Abstrak
Coupler merupakan komponen yang menyambungkan gerbong kereta. Kekuatan coupler terhadap beban eksepsional dan ketahanannya terhadap beban kerja normal menjadi parameter keamanan yang sangat penting dalam operasinya. Kajian ini melakukan analisis deformasi secara numerik terhadap coupling element dari automatic mechanical coupler yang digunakan pada tipe kereta ringan (Light Rail Transit, LRT) berdasarkan beban aktual yang diterima. Bagian coupling element yang diteliti adalah coupling link dan hooked plate. Model solid 3D dibuat tanpa penyederhanaan untuk hasil simulasi yang lebih mendekati fenomena aktual. Material isotropik yang digunakan adalah baja ASTM A633 Grade E. Simulasi statis dan transien dilakukan untuk mendapatkan faktor keamanan statik dan dinamik. Simulasi fatik dari analisis pembebanan transien dengan tiga mode pembebanan dilaksanakan untuk memperkirakan umur kerja coupling element. Hasil simulasi menunjukkan bahwa coupling element yang diobservasi aman terhadap beban eksepsional dan normal yang diberikan. Selain itu, simulasi mengindikasikan bahwa komponen yang kritis berdasarkan tegangan von Mises maksimum adalah coupling link dan komponen yang kritis berdasarkan siklus umur adalah hooked plate.
\end{abstract}

Kata kunci: automatic mechanical coupler, LRT, metode elemen hingga, tegangan von Misses.

\begin{abstract}
Coupler is a mechanical component that used to connect one carbody to another. The resistance to exceptional load and the endurance to normal load become the important parameter of safety in the operation. This study aims to conduct deformation analysis numerically on coupling element of automatic mechanical coupler, which is utilized for light rail transit (LRT), based on actual operational loads. The component of coupling element observed is coupling link and hooked plate. An 3D solid model is developed without any geometric simplification in order to acquire actual phenomenon. Material used in this study is stainless steel that having isotropic behavior and following ASTM standard of A633 Grade E. Three type of simulations are applied, i.e. static and transient simulation, to obtain static and dynamic safety factor of coupling element, and fatigue simulation based on three transient loading modes, to obtain the life cycle of coupling element. The simulation results reveal that the observed coupling element is safe from subjected exceptional and normal service loads. Moreover, the simulation indicates that the critical component based on maximum von Mises stress and life cycle is coupling link and hooked plate, respectively.
\end{abstract}

Keywords: automatic mechanical coupler, LRT, finite element method, von Misses stress.

\section{Pendahuluan}

Pertumbuhan penduduk Indonesia yang terus meningkat perlu diiringi dengan kebutuhan alat transportasi untuk menghemat waktu perjalanan dari suatu tempat ke tempat lain [1]. LRT (Light Rail Transit) merupakan salah satu jenis kereta api penumpang perkotaan yang konstruksinya ringan dan beroperasi di atas permukaan jalan (elevated) yang dinilai sesuai dengan karakter jalan raya di Indonesia. Selama tahun 1990an, proyek transportasi umum seperti LRT direncanakan dan dibangun di Eropa, Amerika Utara dan Jepang. LRT dipilih karena memiliki beberapa keunggulan. Dalam hal mesin, LRT memiliki efisiensi yang relatif lebih tinggi dibandingkan dengan kereta bermesin diesel. Dalam hal carbody, konstruksi carbody LRT cenderung lebih ringan sehingga mem- buat biaya manufaktur menjadi tidak mahal. Selain itu, LRT dirancang memiliki jangkauan yang lebih fleksibel dibandingkan dengan jenis kereta dalam kota yang lain. Apabila dibandingkan dengan bus, LRT dapat memberikan pengalaman menumpang yang lebih halus dan nyaman, bahkan dengan kecepatan lebih cepat, anti macet, dan kapasitas lebih tinggi [2].

Dari beberapa komponen utama LRT, carbody dan coupler sangat memungkinkan untuk diproduksi di dalam negeri. Pada saat ini, LRT yang dioperasikan di Palembang masih menggunakan coupler kereta api biasa, yang mana coupler kereta api biasa mampu menarik beban hingga 40 ton. Padahal gerbong LRT hanya berbobot 12 ton. Oleh karena itu, diperlukan pengembangan coupler yang khusus dipergunakan untuk LRT. 
Studi terhadap coupler kereta api telah banyak dilakukan, diantaranya oleh Wang et al. Mereka menyajikan analisis tegangan dan deformasi coupler tipe knuckle dengan material forging untuk kereta api komersial di China. Pada kajian ini, digunakan dua tipe yaitu beban tarik dan tekan. Semua permodelan dilakukan menggunakan perangkat lunak Catia V5 [3]. Penelitian lain dilakukan oleh Steed dan Kimpton, yakni mengenai analisis kekuatan statik dan umur lelah pada coupler knuckle. Simulasi dilakukan dengan menggunakan perangkat lunak Nastran dan material yang digunakan dalam analisis adalah baja grade B [4]. Penelitian gerak dinamis coupler dilakukan oleh Tainwei dkk., Ziqiang dkk. dan Weihua dkk. Jenis coupler yang digunakan dalam ketiga penelitian ini adalah coupler knuckle. Investigasi mereka menun-jukkan bahwa sudut rotasi coupler sebesar $6^{0}$ me-miliki keselamatan lebih baik daripada sudut bebas $8^{\circ}$. Selain itu, gaya longitudinal yang diberikan pada coupler dapat menghasilkan gaya lateral pada coupler [5][6][7]. Penelitian yang paling mendukung pengem-bangan LRT di Indonesia adalah studi yang dilakukan oleh Priyambodo dan Syaifudin (2018). Mereka mela-kukan optimasi coupler knuckle kereta api berbobot gerbong 42 ton untuk disesuaikan dengan muatan LRT yang berbobot 25 ton. Hasil optimasi yang dilakukan mengusulkan reduksi yang paling optimal, yaitu sebesar $80 \%$ dari desain awal [8].

Hasil penelitian-penelitian tersebut menunjukkan beberapa hal yang perlu diperhatikan dalam manufaktur coupler, khususnya coupler LRT. Dalam hal ini, belum ada studi yang berkaitan langsung dengan perancangan coupler tipe automatic mechanical coupler untuk LRT yang disesuaikan dengan beban kerja aktual dan beban kerja operasional di Indonesia. Kajian ini merupakan tahapan awal pengembangan coupler khusus didesain untuk LRT, yang sedang dikembangkan di Indonesia.

\section{Metode Penelitian}

Permodelan automatic mechanical coupler dibuat dengan Solidworks 2016, sedangkan analisis numerik dilakukan di ANSYS Workbench R18. Bagian yang dianalisis adalah coupling element dari automatic mechanical coupler LRT, yaitu komponen coupling link dan hooked plate. Geometri model ditunjukkan pada Gambar 1(a) dan (b). Gambar 1(c) menunjukkan model elemen hingga setelah diskritisasi. Diskritisasi dilakukan menyesuaikan bentuk komponen, jenis dan jumlah elemen. Koordinat dalam simulasi didefinisikan sebagai sumbu $x$ untuk arah lateral, sumbu $y$ untuk arah vertikal dan sumbu $z$ untuk arah longitudinal.

Material yang digunakan adalah baja ASTM A633 Grade E dengan model material elastik isotropik, seperti ditunjukkan pada Tabel 1 [9]. Untuk analisis kelelahan material, dibutuhkan kurva S-N, seperti ditampilkan pada Gambar 2, sebagai basis untuk mengetahui umur kerja coupling element [10], [11].

Terdapat tiga jenis simulasi pada kajian ini yaitu simulasi statik, transien dan fatik. Simulasi statik digunakan untuk evaluasi kekuatan coupling element terhadap pembebanan eksepsional, simulasi transien digunakan untuk evaluasi kekuatan coupling element terhadap pembebanan kerja normal. Adapun simulasi fatik dilakukan untuk mengetahui umur siklus komponen coupling element akibat pembebanan transien.

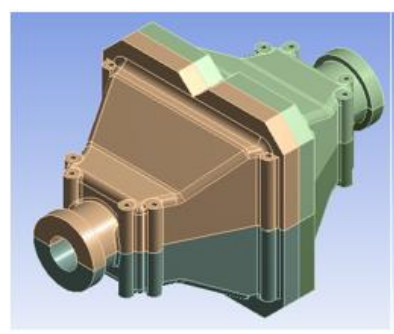

(a)

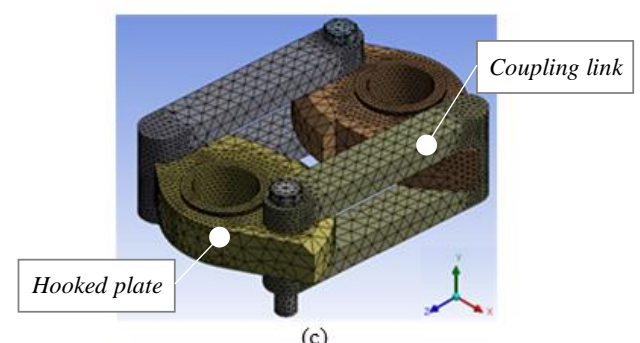

(c)

Gambar 1. (a) Geometri mechanical coupler head, (b) Geometri coupling element, dan (c) Hasil diskritisasi.

Tabel 1. Model material yang digunakan.

\begin{tabular}{ccc}
\hline Sifat Material & Nilai & Satuan \\
\hline Modulus Elastisitas & 200 & $\mathrm{GPa}$ \\
Poisson's ratio & 0,3 & \\
Kekuatan luluh & 687 & $\mathrm{MPa}$ \\
Kekuatan tarik & 823 & $\mathrm{MPa}$ \\
\hline
\end{tabular}

Pada simulasi statik digunakan asumsi beban pada kondisi penumpang penuh, sedangkan pada simulasi transien digunakan asumsi beban penumpang normal. Hal ini sesuai dengan definisi muatan pada kondisi normal dan eksepsional menurut standar muatan kereta di EN 15663:2009 [12]. Penurunan pembebanan untuk masing-masing jenis simulasi dapat dilihat pada Tabel 2. Dalam satu rangkaian trainset LRT, terdapat tiga unit carbody, yaitu motor car (MC1), main car (MC2) dan trailer car (TC).

Kondisi batas simulasi statik ditunjukkan pada Gambar 3, yang mana berupa tumpuan tetap pada pangkal coupler sehingga tidak ada perpindahan ke arah sumbu $x$ dan $y$. Sedangkan gaya tarik dan tekan diberikan pada ujung coupler pasangannya. Kondisi beban tarik mewakili kondisi LRT saat akan melaju dari kondisi diam, sedangkan kondisi tekan mewakili keadaan pengereman. Berdasarkan prinsip keseimbangan benda tegar, diperoleh gaya tarik adalah sebesar $323 \mathrm{kN}$ arah sumbu $z$ dan gaya tekan sebesar $319 \mathrm{kN}$ arah sumbu $-z$. 


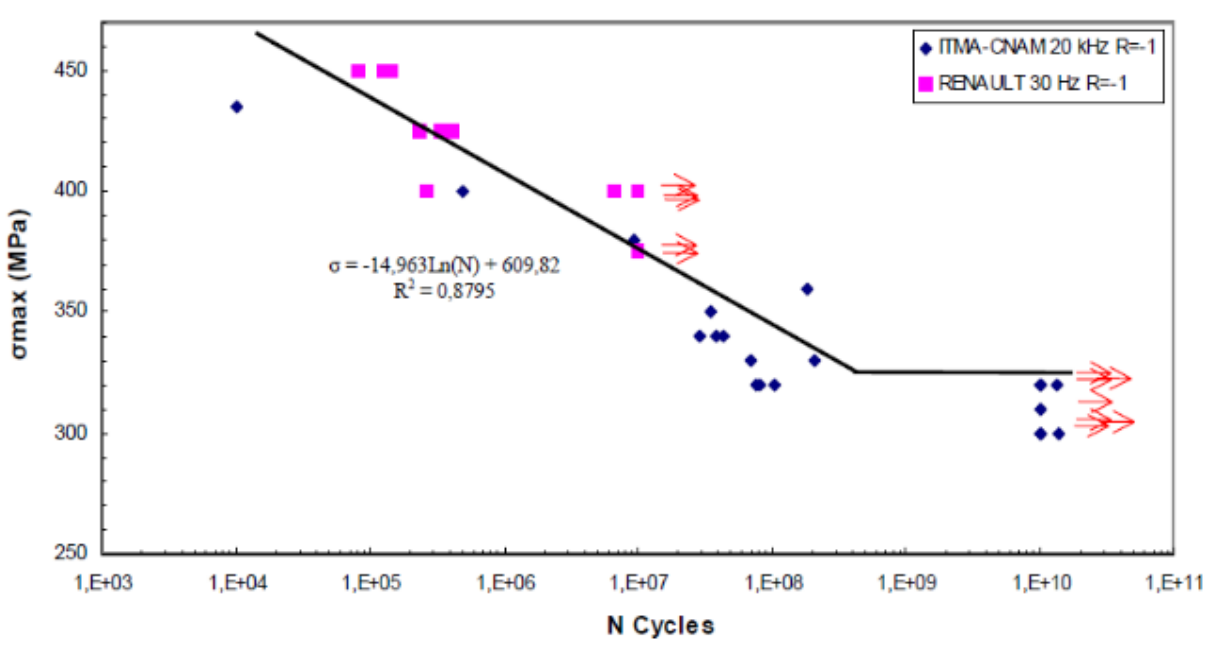

Gambar 2. Kurva digram S-N untuk material A633.

Tabel 2. Jenis pembebanan dalam simulasi.

\begin{tabular}{|c|c|c|c|c|c|c|}
\hline & \multicolumn{3}{|c|}{ Exceptional Load } & \multicolumn{3}{|c|}{ Normal Load } \\
\hline & $\mathrm{MC1}$ & $\mathrm{MC} 2$ & $\mathrm{TC}$ & $\mathrm{MC} 1$ & MC2 & $\mathrm{TC}$ \\
\hline $\begin{array}{c}\text { Berat } \\
\text { penumpang } \\
(\mathrm{kg})\end{array}$ & & 57,7 & & & 57,7 & \\
\hline $\begin{array}{l}\text { Jumlah } \\
\text { penumpang } \\
\text { (orang) }\end{array}$ & 206 & 224 & 224 & 116 & 127 & 127 \\
\hline $\begin{array}{c}\text { Berat } \\
\text { carbody (kg) }\end{array}$ & & 28000 & & & 28000 & \\
\hline $\begin{array}{c}\text { Koefisien } \\
\text { dinamis }\end{array}$ & & 1,3 & & & 1,3 & \\
\hline $\begin{array}{l}\text { Pembebanan } \\
(\mathrm{kg})\end{array}$ & 51852 & 53202 & 53202 & 45101 & 45926 & 45926 \\
\hline $\begin{array}{c}\text { Gravitasi } \\
\text { bumi }\left(\mathrm{m} / \mathrm{s}^{2}\right)\end{array}$ & & 9,81 & & & 9,81 & \\
\hline $\begin{array}{l}\text { Rolling } \\
\text { resistance } \\
\text { (8 roda) }\end{array}$ & 9271 & 9513 & 9513 & 8064 & 8212 & 8212 \\
\hline
\end{tabular}

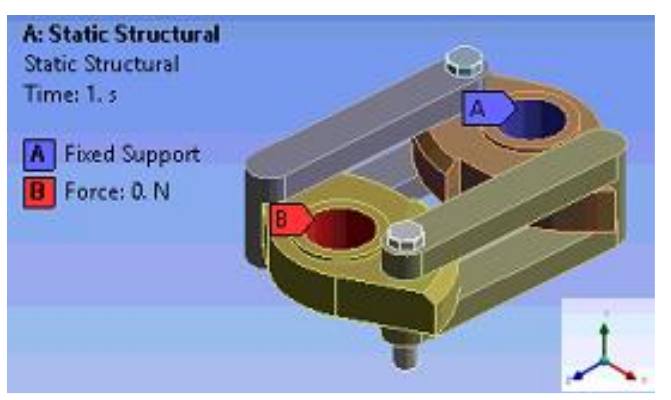

Gambar 3. Pembebanan pada pangkal coupler.

Pada simulasi transien, terdapat tiga mode pembebanan yang diterapkan. Semua jenis beban yang diberikan terletak pada pangkal coupler sebagaimana mode pembebanan statik. Mode pembebanan yang pertama adalah mewakili kondisi saat coupler menerima gaya tarik akibat LRT mulai melaju dari kondisi diam dan gaya tekan dengan sudut kemiringan coupler $0^{\circ}$ saat terjadi pengereman, sehingga tidak ada gaya arah lateral. Pada mode ini digunakan total waktu 0,005 detik. Gaya longitudinal yang diberikan adalah gaya tarik sebesar $323 \mathrm{kN}$ arah sumbu $z$ dan gaya tekan sebesar $319 \mathrm{kN}$ arah sumbu $-z$ dengan perbedaan gaya setiap 0,001 detik.

Mode pembebanan yang kedua mewakili kondisi pengereman, dimana terjadi gaya tekan yang menyebabkan coupler bergerak $6^{0}$ lalu menyebabkan gaya lateral tambahan arah sumbu $x$. Momen gaya yang muncul terjadi karena pemindahan gaya dari bagian coupler yang tersambung dengan carbody ke bagian coupler yang saling bertaut. Pada mode ini digunakan total waktu 0,005 detik. Gaya tekan sebesar $319 \mathrm{kN}$ arah sumbu $-z$, gaya lateral sebesar $34 \mathrm{kN}$ arah sumbu $x$ dan $-x$, dan gaya momen sebesar $9.180 \mathrm{kN}$ dengan perbedaan gaya setiap 0,001 detik.

Adapun mode pembebanan yang ketiga yaitu mewakili kondisi LRT saat akan melaju kemudian melakukan pengereman sehingga terjadi gaya tekan yang menyebabkan coupler bergerak $6^{0}$ lalu menyebabkan gaya lateral arah $x$. Momen gaya yang muncul terjadi karena pemindahan gaya dari bagian coupler yang tersambung dengan carbody ke bagian coupler yang saling bertaut. Sehingga diberikan gaya longitudinal arah $z$ dan $-z$, serta gaya lateral arah $x$ dan $-x$ dengan pengaturan time step pada tabular data. Pada mode terakhir ini total waktu yang digunakan sebesar 0,005 detik. Gaya longitudinal yang diberikan adalah gaya tarik sebesar $323 \mathrm{kN}$ arah sumbu $z$, gaya tekan sebesar $319 \mathrm{kN}$ arah sumbu $-z$, gaya lateral sebesar $34 \mathrm{kN}$ arah sumbu $x$ dan $-x$, dan gaya momen sebesar $9.180 \mathrm{kN}$ dengan perbedaan gaya setiap 0,001 detik.

\section{Hasil dan Pembahasan}

Gambar 7(a) menunjukkan hasil simulasi statik dengan gaya tarik yang diberikan sebesar 374 kN. Dari hasil simulasi didapatkan tegangan von Mises maksimum sebesar 368,59 MPa. Sedangkan Gambar 7(b) 
menunjukkan hasil simulasi statik dengan gaya tekan sebesar $368 \mathrm{kN}$ dan Gambar 7(c) menunjukkan posisi tegangan von Mises maksimum. Tegangan von Mises maksimum yang timbul adalah sebesar $362,68 \mathrm{MPa}$. Posisi tegangan maksimum terdapat pada coupling link yang bersentuhan dengan hooked plate. Intensitas tegangan muncul karena pada bagian tersebut menerima momen reaksi akibat gaya pada hooked plate. Meski momen reaksi ini terdistribusi pada kedua coupling link, namun karena nilainya yang besar menyebabkan munculnya pemusatan tegangan pada bagian tersebut. Dengan demikian, coupling link merupakan komponen kritis yang sangat perlu mendapatkan perhatian dalam perancangan coupler LRT.

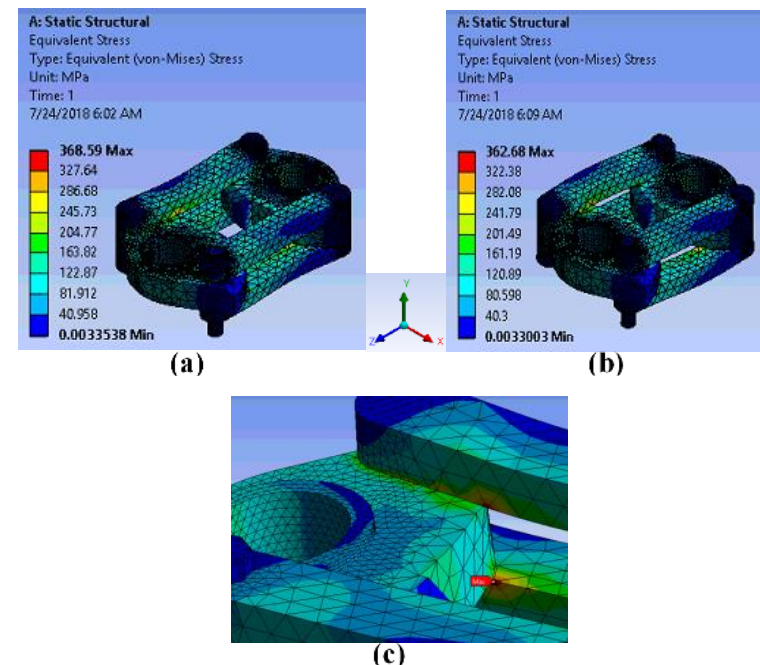

Gambar 7. Distribusi tegangan von Mises pada simulasi statik: (a) Akibat beban tarik, (b) Akibat beban tekan, dan

(c) Lokasi tegangan maksimum.

Gambar 8 menunjukkan perbandingan tegangan von Misses maksimum dari simulasi transien dengan variasi mode pembebanan yang berbeda. Pada mode pembebanan yang pertama hingga ketiga didapatkan nilai tegangan von Mises maksimum berturut-turut sebesar 162,55 MPa, 50,39 MPa, dan 188,42 MPa. Tampak dengan jelas bahwa tegangan von Mises maksimum yang paling besar terjadi pada kondisi pembebanan ketiga, yaitu ketika pemberian gaya lateral dan longitudinal sebagai akibat dari awal melajunya kereta dari posisi diam dan pengereman kereta ke posisi diam dengan kemiringan coupler $6^{0}$. Posisi tegangan maksimum mirip dengan hasil simulasi statik, yakni pada coupling link yang bersentuhan dengan hooked plate, sebagaimana ditampilkan pada Gambar 9. Hal penting yang ditampilkan oleh kedua jenis simulasi adalah bahwa coupling link menjadi komponen kritis yang sangat memerlukan perhatian lebih dalam perancangan mechanical head coupler. Berdasarkan karakteristik pembebanan yang diterima, peningkatan ketahanan terhadap beban bending perlu ditekankan pada proses manufaktur coupling link.

Faktor keamanan adalah parameter yang biasa digunakan untuk menunjukkan tingkat kekuatan suatu komponen mekanik terhadap beban statik, baik yang bersifat konstan maupun sesaat (impak). Pada dasarnya, faktor keamanan hanya diperuntukkan untuk mode pembebanan statik. Namun dalam kasus quasistatic atau transien, yang mana pembebanan fluktuatif terjadi secara sesaat sehingga seakan-akan mendekati keadaan statik, maka parameter faktor keamanan juga dapat diperhitungkan. Dari definisi ini, maka muncullah pengertian faktor keamanan untuk kondisi statik dan dinamik, yang mana untuk kondisi statik berada dalam rentang nilai $1,0-2,0$ dan untuk kondisi dinamik berada dalam rentang nilai $2,0-3,0$. Sedangkan untuk pembebanan dinamik murni yang menghasilkan tegangan yang berfluktuasi, parameter siklus hidup lebih tepat untuk menggambarkan ketahanan suatu komponen mekanik [13], [14].

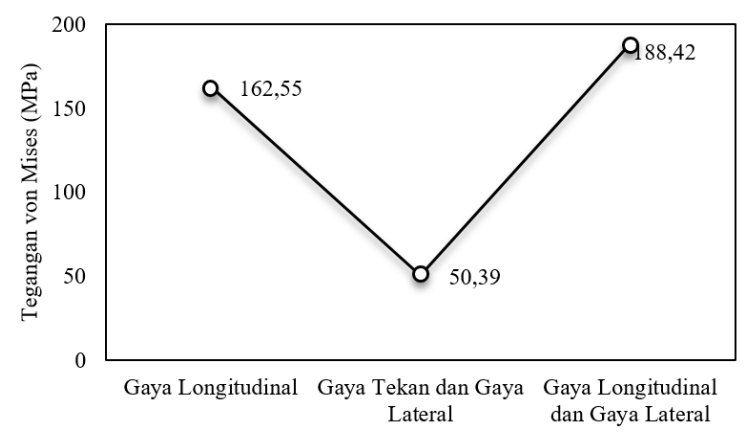

Gambar 8. Tegangan von Mises maksimal hasil simulasi transien.

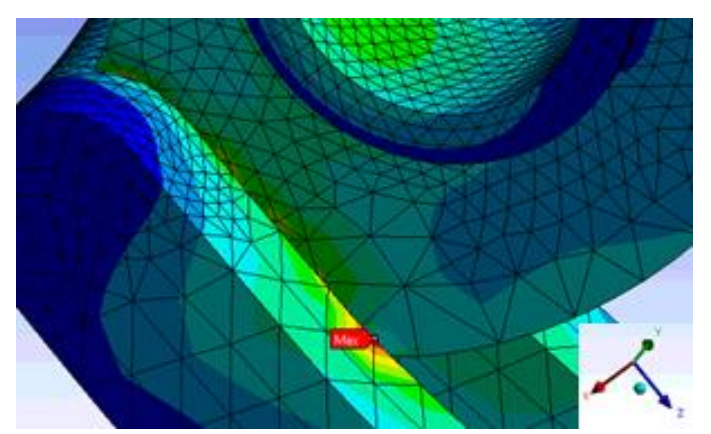

Gambar 9. Posisi tegangan von Mises maksimum pada simulasi transien

Gambar 10(a) dan (b) menunjukkan distribusi faktor keamanan pada simulasi statik, masing-masing akibat beban tarik dan tekan. Akibat beban tarik, nilai faktor keamanan yang didapatkan sebesar 1,87. Sedangkan akibat beban tekan, nilai faktor keamanan yang diperoleh sebesar 1,89. Baja ASTM A633 Grade E, sebagai material coupling element, memiliki kekuatan luluh sebesar $687 \mathrm{MPa}$ dan kekuatan tarik maksimum sebesar $823 \mathrm{MPa}$. Dengan mengacu pada nilai kekuatan tarik maksimum material tersebut, dengan demikian dapat dismpulkan bahwa nilai faktor keamanan yang diperoleh masih berada dalam rentang keamanan statik $(\mathrm{N}=1,0-2,0)$ dan komponen tidak akan mengalami deformasi permanen saat menerima beban tarik maupun tekan. 


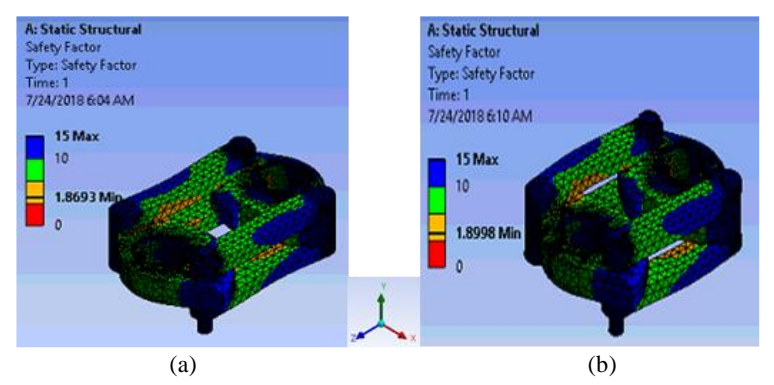

Gambar 10. Faktor keamanan pada simulasi statik: (a) Akibat beban tarik, dan (b) Akibat beban tekan.

Tabel 3 menunjukkan faktor keamanan hasil simulasi transien untuk berbagai mode pembebanan, dengan mengacu pada nilai kekuatan tarik maksimum material yang sebesar $823 \mathrm{MPa}$. Tampak jelas bahwa mode pembebanan ketika pengereman adalah kondisi yang paling aman. Selain itu, nilai faktor keamanan dari ketiga simulasi melebihi rentang aman untuk simulasi dinamik $(\mathrm{N}=2,0-3,0)$. Oleh karena itu, dapat disimpulkan bahwa komponen coupling element juga masih berada dalam keadaan aman.

Tabel 3. Jenis pembebanan dalam simulasi.

\begin{tabular}{cc}
\hline Kondisi Pembebanan & $\begin{array}{c}\text { Faktor } \\
\text { Keamanan }\end{array}$ \\
\hline Gaya longitudinal & 4,24 \\
Gaya tekan dan Gaya lateral & 13,63 \\
Gaya longitudinal dan Gaya lateral & 3,65 \\
\hline
\end{tabular}

Banyak komponen mekanik yang mampu bekerja dengan baik pada awal penggunaannya. Namun komponen mekanik tersebut pada akhirnya sering mengalami kerusakan bukan akibat beban statik yang berlebih, melainkan akibat beban berfluktuasi yang berulang-ulang (beban fatik). Meski beban fatik yang terjadi masih jauh dari batas kekuatan luluh material, namun sangat penting untuk diperhatikan.

Analisis siklus hidup diperlukan untuk memperkirakan umur suatu komponen mekanik dalam menerima beban fluktuatif. Dalam ANSYS Workbench, terdapat dua jenis metode yang dapat dipilih untuk memperkirakan umur komponen, yaitu stress life dan strain life. Stress life didasarkan pada kurva S-N dengan jumlah siklus yang diperkirakan melebihi $10^{5}$ siklus atau infinite life, sehingga mengakomodasi asumsi bahwa hanya terjadi regangan elastik pada komponen. Sedangkan strain life didasarkan pada persamaan Neuber (Neuber's Rule) untuk menghubungkan regangan dan tegangan sehingga diperoleh jumlah siklus yang kurang dari $10^{5}$. Metode strain life mengakomodasi terjadinya regangan elastik dan plastik pada komponen, sehingga sangat sesuai untuk memprediksi munculnya awal retakan (crack initiation) pada komponen mekanik [15], [16]. Dari kedua metode tersebut, asumsi stress life lebih mudah untuk diterapkan dan lebih sesuai dengan tujuan perancangan komponen mekanik. Oleh karena itu, dalam analisis numerik ini dipilih metode stress life untuk memperkirakan umur coupling element. Dalam ANSYS Workbench, analisis siklus hidup dapat diselesaikan dengan fitur Fatigue Tool, yang mana dapat diakses melalui simulasi statik maupun transien.

Siklus hidup hasil simulasi transien akibat beban longitudinal dan lateral dapat ditunjukkan pada Gambar 11. Siklus hidup yang diamati dalam simulasi pembebanan ini hanya pada mode pembebanan ketiga, karena mode ini merupakan kondisi pembebanan yang mengakibatkan tegangan von Mises maksimum yang paling besar diantara yang lain. Hasil simulasi mengindikasikan bahwa jumlah siklus umur coupling element yang paling rendah adalah sebesar $10^{6}$ siklus, dimana terletak pada area hooked plate. Hasil simulasi fatik ini agak sedikit berbeda dibandingkan dengan hasil simulasi statik dan transien, yakni munculnya perbedaan komponen kritis pada masing-masing jenis simulasi. Hal ini bisa disebabkan oleh perbedaan distribusi tegangan rata-rata dan amplitudo yang terjadi. Pada simulasi fatik, hasil distribusi umur sangat dipengaruhi oleh besarnya tegangan rata-rata dan amplitudo. Sedangkan pada simulasi statik atau transien, nilai tegangan von Mises yang maksimum belum tentu menunjukkan nilai tegangan rata-rata atau tegangan amplitudo yang maksimum pula.

Adapun nilai siklus sebesar $10^{6}$ adalah nilai siklus yang masih sangat dipengaruhi oleh frekuensi tegangan amplitudo yang terjadi pada hooked plate. Apabila rasio frekuensi tegangan amplitudo terhadap siklus adalah lebih dari satu, maka umur komponen hooked plate akan semakin rendah. Dengan demikian, hooked plate juga perlu mendapatkan perhatian lebih karena memiliki umur siklus yang lebih rendah dibandingkan dengan coupling link.

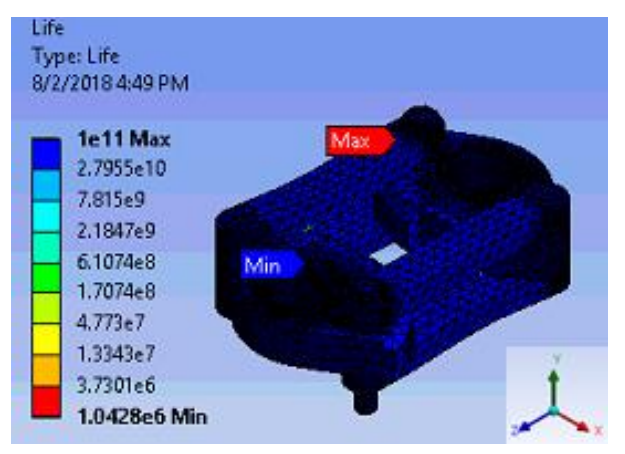

Gambar 11. Umur kerja coupling element terhadap tegangan longitudinal dan tegangan lateral.

\section{Kesimpulan}

Melalui kajian numerik ini dapat disimpulkan bahwa coupling element dari automatic mechanical coupler aman terhadap beban eksepsional dan normal yang aktual diberikan. Simulasi statik yang dilakukan dapat menunjukkan kekuatan coupling element terhadap beban eksepsional aktual dan simulasi transien dapat menunjukkan ketahanan coupling element terhadap beban normal aktual. 
Tegangan von Misses maksimum sebesar 368,59 MPa terjadi ketika dilakukan pemberian gaya tekan pada coupler, dimana setara dengan $44,79 \%$ dari kekuatan tarik maksimum material. Dalam hal angka keamanan, tegangan yang timbul menghasilkan nilai faktor keamanan 1,87 yang menunjukkan masih berada dalam rentang aman untuk faktor keamanan statik. Sedangkan nilai tegangan von Misses maksimum sebesar 188,42 MPa muncul dalam kondisi pembebanan normal dengan gaya longitudinal dan lateral pada sudut kemiringan coupler $6^{\circ}$. Tegangan ini setara dengan $22,89 \%$ dari kekuatan tarik maksimum material. Nilai faktor keamanan ini $(3,65)$ juga terjadi pada kondisi pembebanan yang sama, dimana nilai ini masih berada dalam rentang faktor keamanan dinamik.

Dengan simulasi fatik, umur kerja yang paling rendah untuk coupling element adalah sekitar $10^{6}$ siklus, yang terjadi pada area hooked plate. Adapun dari analisis faktor keamanan pada simulasi statik dan transien, diketahui bahwa coupling element adalah komponen yang paling kritis, karena komponen ini memiliki nilai faktor keamanan yang paling rendah.

\section{Daftar Pustaka}

[1] Badan Pusat Statistik Indonesia. 2013, Proyeksi Penduduk Indonesia Indonesia Population Projection 2010-2035, no. 6.

[2] B. Hylén and T. Pharoah. 2002, "Making Tracks - Light Rail in England and France," pp. 22-85.

[3] G. X. Wang, X. S. Bu, L. J. Li, and L. L. Zhu. 2013, "The Finite Element Analysis of New Forged Coupler Knuckle,” Appl. Mech. Mater., vol. 367, pp. 122-125.

[4] J. Steed. 2015, "Improving the 10" Head Alliance Coupler and Knuckle," no. June.

[5] S. L. \& R. S. Weihua Ma. 2012, "Coupler dynamic performance analysis of heavy haul locomotives," Veh. Syst. Dyn., vol. 50, no. August 2012, pp. 37-41.

[6] Z. Xu, W. Ma, Q. Wu, and S. Luo. 2014, "Analysis of the rotation angle of a coupler used on heavy haul locomotives," Proc. Inst. Mech. Eng. Part F J. Rail Rapid Transit, vol. 228, no. 8, pp. $835-844$.

[7] Q. Tianwei, M. Weihua, W. Dong, and L. Shihui. 2015, "Influence of coupler and buffer on dynamics performance of heavy haul locomotive," Open Mech. Eng. J., vol. 9, no. 1, pp. 1033-1038.

[8] A.M. Priyambodo and A. Syaifudin. 2019, "Perancangan Coupler untuk LRT di Indonesia," J. Tek. ITS, vol. 7, no. 2, pp. 87-92.

[9] AAR Standards. 2000, "AAR Manual of Standards and Recommended Practices Couplers and Freight Car Draft Components STEEL CASTINGS Specification Adopted: 1923 ; Revised: 1984 , 1993 , 2000 AAR Manual of
Standards and Recommended Practices Couplers and Freight Car Draft Compone," pp. 4-11.

[10] I. Marines-García, D. Galván-Montiel, and C. Bathias. 2008, "Fatigue Life Assessment of High-Strength , Low- Alloy Steel At High Frequency," Arab. J. Sci. Eng., vol. 33, no. 1, pp. 237-247.

[11] V. Shankar, K. Mari, R. Sandhya, and M.D. Mathew. 2013, "Evaluation of Low Cycle Fatigue Damage in Grade 91 Steel Weld Joints for High Temperature Applications," vol. 55, pp. 128-135.

[12] European Committee for Standardization. 2009, "EN 15663 2009: Railway applications Definition of vehicle reference masses.pdf,".

[13] R.G. Budynas, J.K. Nisbett, and J.E. Shigley. 2015, Shigley's Mechanical Engineering Design, 10th ed.

[14] R.L. Norton, 2013. "Machine Design: An Integrated Approach", 5th ed.

[15] ANSYS Workbench R18. 2018, "Theory Reference Manual", ANSYS Inc.

[16] R.L. Browell and Al Hancq, 2006. "Predicting Fatigue Life with ANSYS Workbench: How To Design Products that Meet Their Intended Design Life Requirements". ANSYS Inc. 